\title{
Pulmonary artery aneurysm in an adult patient with idiopathic dilatation of the pulmonary artery
}

\author{
Katarzyna Betkier-Lipińska ${ }^{1}$, Grzegorz Suwalski ${ }^{2}$, Sebastian Czarkowski ${ }^{3}$, Piotr Hendzel ${ }^{2}$, Andrzej Cwetsch ${ }^{1}$ \\ ${ }^{1}$ Department of Cardiology, Military Institute of Medicine, Warsaw, Poland \\ 2Department of Cardiac Surgery, Military Institute of Medicine, Warsaw, Poland \\ ${ }^{3}$ Department of Clinical Radiology, Military Institute of Medicine, Warsaw, Poland
}

Kardiochirurgia i Torakochirurgia Polska 2015; 12 (4): 341-344

\begin{abstract}
Idiopathic dilatation of the pulmonary artery (IDPA) is a rare congenital heart disease. It has been described for almost one hundred years, and numerous definitions have been proposed. The IDPA diagnostic criteria have not been updated for years. Secondary to primary disease, pulmonary artery aneurism was recognised as a lethal defect; however, long-term follow-up of patients with IDPA has not been well researched. Thus, indications to medical or surgical treatment are not evidence based. Here, we present a rare case of a 54-year-old patient with IDPA, who remained under observation for 36 years without surgical intervention.

Key words: pulmonary artery dilatation, main pulmonary artery.
\end{abstract}

\section{Case report}

A 54-year-old male patient with main pulmonary artery (MPA) dilatation detected in out-clinically performed computed tomography (CT) and with well controlled arterial systemic hypertension was referred to our department for advanced diagnostics and for a further therapy decision to be made. His first hospitalisation due to congenital heart disease suspicion was at the age of 18. At that time there were no clinical symptoms besides the presence of protomezosystolic murmur over the left sternal edge and cardiac apex. In chest X-ray tomography performed at that time enlargement of the left pulmonary artery was found. In those days - in 1976 - atrial septal defect was suspected and the patient was referred for haemodynamic and angiographic studies. However, it was abandoned due to lack of compliance. In 2003 diagnostic procedures were restarted, and CT revealed MPA dilatation to $40 \mathrm{~mm}$.

During the present hospitalisation the patient denied the presence of any cardiovascular symptoms and con-

\section{Streszczenie}

Idiopatyczne poszerzenie pnia tętnicy płucnej (idiopathic dilatation of the pulmonary artery - IDPA) jest rzadką wrodzoną wadą serca. Jednostka ta została opisana ponad 100 lat temu i na przestrzeni czasu stworzono szereg jej definicji. Niemniej od wielu dekad nie aktualizowano kryteriów diagnostycznych ani wytycznych leczenia. Tętniak tętnicy płucnej na podłożu innym niż IDPA może być wadą letalną. Odległe rokowanie u pacjentów z IDPA nie jest dobrze poznane, dlatego wskazania do leczenia farmakologicznego oraz chirurgicznego nie są oparte na dostatecznych danych naukowych. W pracy zaprezentowano przypadek 54-letniego pacjenta z IDPA, u którego udokumentowano systematyczne poszerzanie się pnia tętnicy płucnej i który pozostawał w obserwacji przez 36 lat bez konieczności podjęcia leczenia chirurgicznego.

Słowa kluczowe: poszerzenie tętnicy płucnej, pień tętnicy płucnej.

firmed regular physical activity. Examination revealed only slight systolic murmur (Levine 1/6) over the left sternal edge. Electrocardiography (ECG) study was normal. Chest $X$-ray revealed enlargement of the left hilum probably due to enlargement of the main pulmonary artery (Fig. 1). Echocardiography showed proximal MPA diameter of $29 \mathrm{~mm}$ distally exceeding to $45 \mathrm{~mm}$. The right pulmonary artery (RPA) was enlarged up to $29 \mathrm{~mm}$, and the left one was not precisely visible. Blood flow profile was normal. No signs of intracardiac or extracardiac shunting were found. Right ventricule diameter and contractility were normal (RVdD - $29 \mathrm{~mm}$ ) without symptoms of pulmonary hypertension (TRPG - $20 \mathrm{mmHg}$ ). Cardiac CT revealed MPA aneurysm $(47 \times 40 \mathrm{~mm}$ in diameter) with significant enlargement of the left $(37 \times 35 \mathrm{~mm})$ and right pulmonary artery $(24 \times 27 \mathrm{~mm}$; Figs. 1 and 2). Potential primary causes of MPA dilatation were eliminated, such as: distal MPA stenosis, pulmonary embolism, and the presence of any pulmonary disease. Coronary arteries CT scan was performed

Address for correspondence: Grzegorz Suwalski, MD, PhD, Department of Cardiac Surgery, Military Institute of Medicine, 128 Szaserów St., 04-141 Warsaw, Poland, phone: +49 508117 590, e-mail: grzegorz.suwalski@wp.pl 


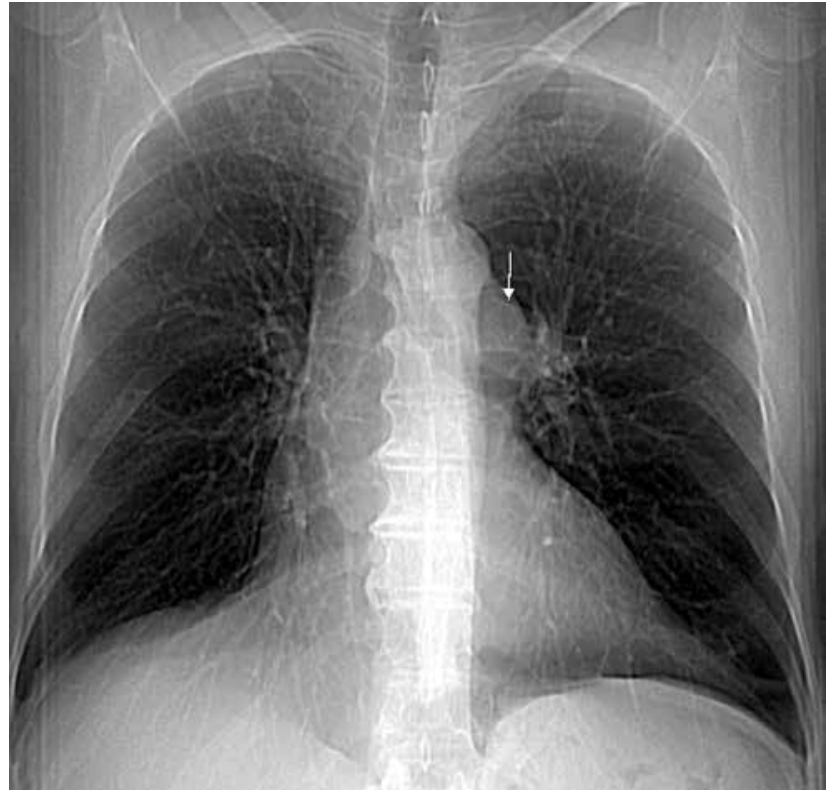

Fig. 1. Chest X-ray showing enlargement of left hilum probably due to main pulmonary artery dilatation

and showed no signs of left coronary artery compression with MPA aneurysm (Fig. 3). Additional laboratory studies excluded inflammatory and collagen disorders. According to the gathered data a diagnosis of idiopathic dilatation of the main pulmonary artery (IDPA) was stated. At that time the patient was disqualified from surgical intervention. The following therapy was targeted at optimal medical management of arterial systemic hypertension. Future control tests after 6 and 10 months were planned.

After six months control echocardiography showed a proximal MPA diameter of $28 \mathrm{~mm}$ with enlargement progression of the distal segment to $51 \mathrm{~mm}$ and RPA to $31 \mathrm{~mm}$. Right ventricule diastolic diameter was also enlarged to $41 \mathrm{~mm}$ with preserved contractility. Computed tomography study revealed progression of MPA diameters to $52 \times$

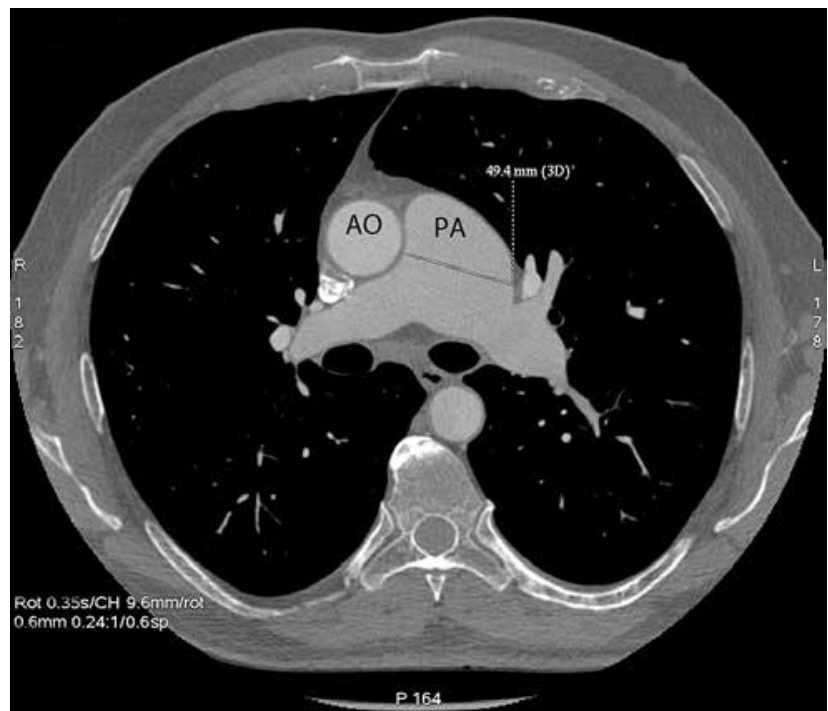

Fig. 3. Main pulmonary artery dilatation with right and left pulmonary artery enlargement (computed tomography study)

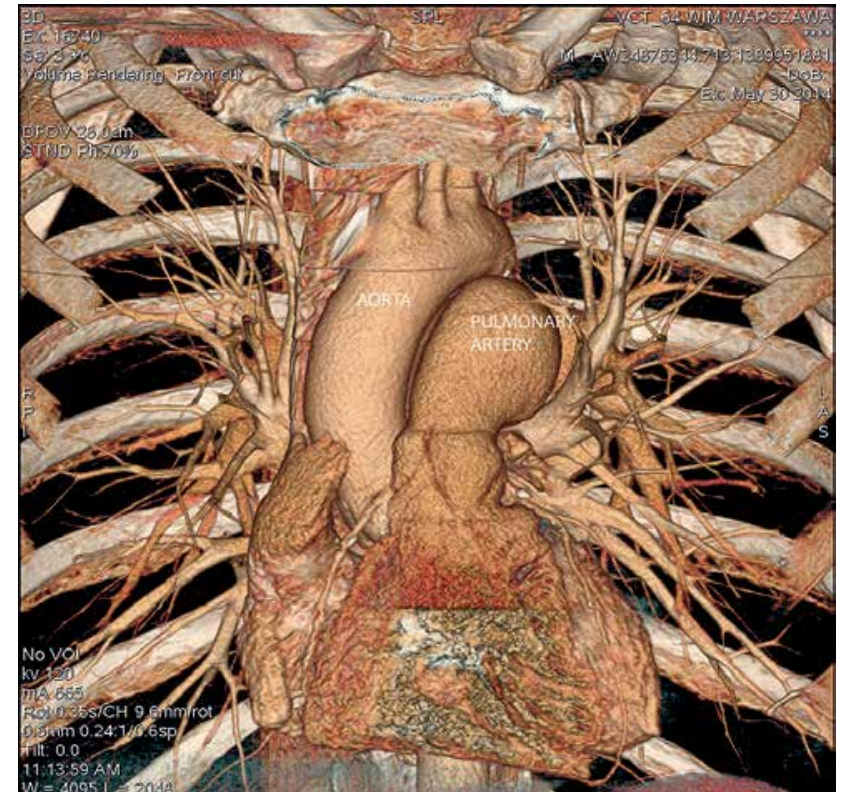

Fig. 2. Main pulmonary artery dilatation (computed tomography reconstruction)

$45 \mathrm{~mm}$, LPA diameter to $36 \times 27 \mathrm{~mm}$, and RPA diameter to $30 \times 26 \mathrm{~mm}$. After the next four months an echocardiography study showed stable parameters of pulmonary arteries with MPA enlargement progression to $57 \mathrm{~mm}$. The patient was continuously disqualified from surgical treatment due to asymptomatic course. Continuation of optimal medical therapy of arterial hypertension was administered.

\section{Discussion}

Isolated pulmonary artery enlargement, also known as idiopathic dilatation of the pulmonary artery, is a rare congenital defect with a prevalence of $0.6 \%$ of all congenital heart defects (CHD) [1, 2]. Approximately in 1 per 14,000 autopsies MPA aneurism is recognised [3]. The first description of IDPA was published by Wessler and Jaches in 1923

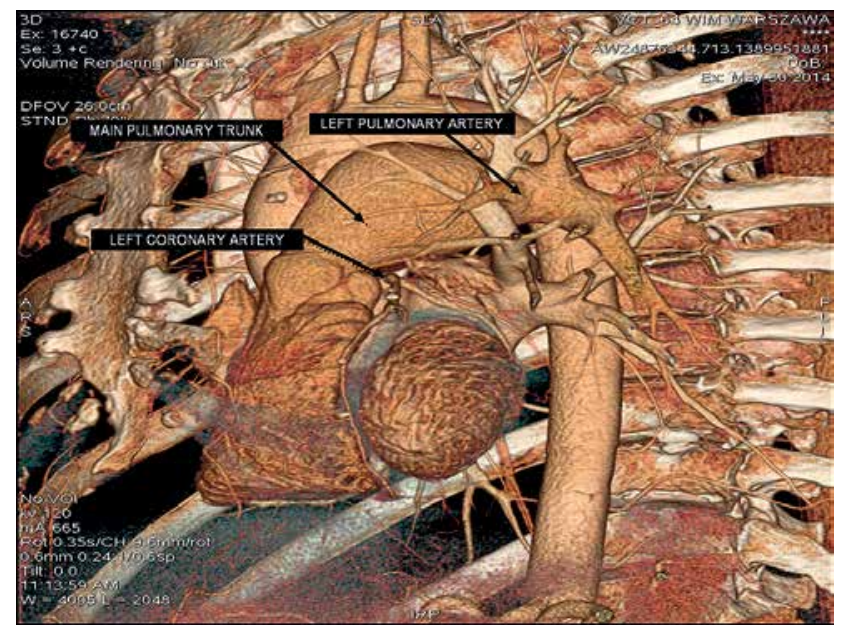

Fig. 4. Computed tomography scan showing pulmonary artery aneurism with no compression on left coronary artery 
[4]. Clinical criteria of IDPA diagnosis were first presented by Green in 1949 and improved in 1960 by Desmukh [5, 6]. According to them, IDPA may be diagnosed if: isolated MPA diameter exceeds $30 \mathrm{~mm}$ with or without pulmonary arteries enlargement, there is an absence of intra or extracardiac shunt, cardiac or pulmonary disorders, arterial wall pathologies (i.e. atherosclerosis, callosity, syphilis), and with normal pulmonary artery and right ventricule pressure. Actually due to the availability of more accurate diagnostic tools further criteria were added: ratio of pulmonary artery bifurcation and aortic annulus diameters more than 1.4 and/or ratio of MPA and aortic annulus diameters more than 1.5. However, there are no precisely defined normal ranges of MPA diameter. It is accepted that MPA should not exceed $30 \mathrm{~mm}$ or MPA diameter should not be larger than aortic diameter on the corresponding level. It should be noted that those criteria apply to pulmonary artery dilatation in patients with pulmonary hypertension but not to IDPA [7].

Until now the aetiology of IDPA has not been clearly defined. Post-mortem histopathological studies showed mucopolysaccharide deposits in the tunica media of the MPA, which is similarly detected in cystic medial necrosis. Thus, IDPA may be caused by unidentified connective tissue pathology [8].

In the vast majority of cases IDPA remains asymptomatic. Usually it is accidentally diagnosed while chest X-ray shows significant enlargement of the left pulmonary hilum. Clinical manifestation involves non-specific angina, dyspnoea, exercise intolerance, cough, and haemoptysis. Those symptoms result from aneurismal compression on contiguous anatomical structures. According to some authors, in patients with IDPA a physical examination may reveal: systolic murmur over the left sternal edge (up to $3 / 6$ in the Levine scale) with maximal force in $2^{\text {nd }}$ or $3^{\text {rd }}$ intercostal space, the presence of pulmonary click, and $2^{\text {nd }}$ tone split $[9,10]$. Since those symptoms are not specific final diagnostics require echocardiography with MPA diameter calculation, evaluation of valve morphology and function, and exclusion of pulmonary hypertension. Following CT and cardiac magnetic resonance studies are advised. In some cases cardiac catheterisation is desired for adequate pulmonary artery pressure assessment [11].

The occurrence of spontaneous dissection of pulmonary artery aneurism in patients with IDPA is extremely rare [12]. Van Rens et al. reported a case of 39-year-long uneventful follow-up of a patient with untreated IDPA [13]. Thus, it is crucial in the diagnostic process to exclude the possibility of secondary MPA enlargement to CHD, patent ductus arteriosus, pulmonary artery stenosis, pulmonary hypertension, MPA infection (bacterial, mycotic, tuberculotic and syphilic), vascular inflammatory process (Behcet disease, Huges-Stovin disease), and connective tissue defects (Marfan or Ehlers-Danlos syndrome) [14]. It is accepted that pulmonary artery aneurism secondary to other diseases is lethal. Most available data are gathered in populations with pulmonary hypertension [15]. The main causes of death in patients with pulmonary hypertension and pulmonary artery aneurism are dissection and rapture of aneurism [16].
There are no unequivocal indications for management in IDPA. Medical treatment does not affect primary pathology and seems to be ineffective. Some authors support the thesis that all patients with pulmonary artery aneurism should be referred for surgical intervention. Others advocate that patients presenting clinical symptoms (dyspnoea, chest pain, haemoptysis), dynamic progression of MPA enlargement, or dissection should only be treated surgically due to high mortality risk $[17,18]$.

Since the majority of data show that rupture of an MPA aneurism occurs mostly in patients with primary disease, such as connective tissue disorder, pulmonary hypertension, or mycotic infection, it remains rational to refer all symptomatic patients with secondary pulmonary artery aneurism for surgical intervention $[19,20]$. Veldtman et al. suggest that the timing of the surgical procedure in the population with pulmonary hypertension should be additionally guided with right ventricule dimension, function and presence of pulmonary regurgitation, or stenosis, regardless of MPA size [21].

Several surgical procedures were elaborated to treat secondary pulmonary aneurism. Those techniques might be incorporated into IDPA if the decision to go ahead with surgical treatment is made. Longitudinal plication of MPA (aneurysmorrhaphy) may be performed without use of cardiopulmonary bypass and is relatively less technically demanding. However, plication should not be performed in patients with connective tissue disorder or CHD since the risk of further enlargement of MPA is high. Definitive correction may be achieved by total aneurysmectomy and repair with Dacron or Gore-Tex graft or autologous pericardial replacement [22]. In patients with severe pulmonary artery valve dysfunction due to pulmonary artery valve dilatation reconstruction of right ventricule outflow tract (RVOT) might be needed. For that purpose the use of homograft, porcine aortic xenograft, or bovine jugular vein is indicated. A few authors have reported the feasibility of percutaneous coronary artery angioplasty with stent implantation due to coronary artery compression by MPA aneurism. In such cases it is recommended that precise visualisation of compressed artery segment be performed with use of computed tomography since standard angiography may not be sufficient $[23,24]$.

In conclusion, in the presented case we confirmed constant progression of pulmonary artery dilatation since it was first observed more than ten years previously. However, right ventricule function has been preserved and the patient is currently free from any symptoms. Idiopathic dilatation of the main pulmonary artery diagnosis is stated since other primary causes were eliminated. The heart team agreed that currently the risk of surgical intervention is higher than the potential benefit. The patient is scheduled for frequent control follow-up and will be operated if any symptoms occur.

\section{Disclosure}

Authors report no conflict of interest. 


\section{References}

1. Abott M. Atlas of Congenital Cardiac Disease. American Heart Association, New York 1936.

2. Ugolini P, Mousseaux E, Sadon Y, Sidi D, Mercier LA, Paquet E, Gaux JC. Idiopathic dilatation of the pulmonary artery: report of four cases. Magn Reason Imagining 1999; 17: 933-937.

3. Deterling RA Jr, Clagett T. Aneurysm of the pulmonary artery: review of the literature and report of a case. Am Heart J 1947; 34: 471-499.

4. Wessler H, Jaches L. Clinical Roentgenology of Disease of the Chest. Southworth, Troy 1923; 26.

5. Greene DG, Baldwin EF, Baldwin JS, et al. Pure congenital pulmonary stenosis and idiopathic congenital dilatation of the pulmonary artery. Am J Med 1949; 6: 24-40.

6. Deshmukh M, Guvenc S, Bentigoglio L, Goldberg H. Idiopathic dilatation of the pulmonary artery. Circulation 1960; 21: 710-716.

7. Kurzyna M. Ocena przyczyn i konsekwencji występowania tętniaka tętnicy płucnej u pacjentów z nadciśnieniem płucnym; available at: www.statsoft.pl.

8. Andrews R, Colloby P, Hubner PJ. Pulmonary artery dissection in a patient with idiopathic dilatation of the pulmonary artery: a rare cause of sudden cardiac death. Br Heart J 1993; 69: 268-269.

9. Dayioglu E, Sever K, Basaran M, Dayioglu E, Sever K, Basaran M, Kafali E, Ugurlucan M, Sayin OA, Karafaki S, Alpagut U, Tansel T. Idiopathic pulmonary artery aneurysm. IJTCVS 2004; 20: 140-141.

10. Sanoussi A, Sokolow Y, Cappello M. The management of a pulmonary artery aneurysm. Acta Chir Belg 2009; 109: 248-249.

11. Asayama J, Matsuura T, Endo N, Watanabe T, Matsukubo H, Furukawa K, ljichi H. Echocardiographic findings of idopathic dialtation of the pulmonary artery. Chest 1977; 71: 671-673.

12. Inayama Y, Nakatni Y, Kitamura H. Pulmonary artery dissection in patients without underlying pulmonary hypertension. Histopathology 2001; 38: 435-442.

13. van Rens M, Westermann C, Postmus P, Schramel F. Untreated idiopathic aneurism of the pulmonary artery: long-term follow-up. Resp Med 2000; 94: 404-405.

14. Durieux P, Bletry O, Huchon G, Wechsler B, Chretien J, Godeau P. Multiple pulmonary arterial aneurysms of Behcet's diseases and Hughes-Stovin syndrome. Am J Med 1981; 71: 736-741.

15. Walley VM, Virmani R, Silver MD. Pulmonary arteria dissections and ruptures: to be considered in patients with pulmonary arteria hypertension presenting with cardiogenic shock or sudden death. Pathology 1990; 22: 1-4.

16. Steurer J, Jenni R, Medici TC, Vollrath T, Hess OM, Siegenthaler W. Dissecting aneurysm of the pulmonary artery with pulmonary hypertension. Am Rev Resp Dis 1990; 142: 2329-2321.

17. Chen YF, Chiu CC, Lee CS. Giant aneurysm of the main pulmonary artery. Ann Thorac Surg 1996; 62: 272-274.

18. Senbaklavaci O, Kaneko Y, Bartunek A, Senbaklavaci O, Kaneko Y, Bartunek A, Brunner C, Kurkciyan E, Wunderbaldinger P, Klepetko W, Wolner E, Mohl W. Rupture and dissection in pulmonary artery aneurysms: incidence, cause and treatment: a review and case report. J Thorac Cardiovasc Surg 2001; 121: 1006-1008.

19. Smalcelj A, Brida V, Samarzija M, Matana A, Margetic E, Drinkovic N. Giant, dissecting, high-pressure pulmonary artery aneurysm: case report of a 1-year natural course. Tex Heart Inst J 2005; 4: 589-594.

20. Benveniste O, Bruneel F, Bédos JP, Wolff M, Lesèche G, Leport C, Vildé JL, Vachon F, Régnier B. Ruptured mycotic pulmonary artery aneurysm: an unusual complication of right-sided endocarditis. Scand J Infect Dis 1998; 6: 626-629.

21. Veldtman GR, Dearani JA, Warnes CA. Low pressure giant pulmonary artery aneurysms in the adult: natural history and management strategies. Heart 2003; 89: 1067-1070

22. Kuwaki K, Morishita K, Sato H, Urita R, Abe T. Surgical repair of the pulmonary trunk aneurysm. Eur J Cardiothorac Surg 2000; 18: 535-539.

23. Bonderman D, Fleischmann D, Prokop M, Klepetko W, Lang IM. Left main coronary artery compression by the pulmonary trunk in pulmonary hypertension. Circulation 2002; 105: 265.

24. Kępka C, Dzielińska Z, Torbicki A, Kurzyna M, Chmielak Z, Pracoń R, Florczyk M, Wieteska M, Pręgowski J, Kruk M, Demkow M. Acute coronary syndrome caused by compression of the left main coronary artery - the usefulness of computed tomography in diagnosis and interventional treatment planning. Postep Kardiol Interw 2012; 8: 61-65. 